\title{
Educational Philosophy in the Effect of Globalization on Agriculture
}

\author{
Aslan Riyadh \\ University of Jijel, Algeria
}

\begin{abstract}
Technological advances due to the rapid flow of globalization, change the pattern of teaching in the world of education. The philosophy of education shows a vertical relationship, up or down with the branches of education. It is hoped that the public can better understand the importance of globalization so that the negative impacts that have an impact can be minimized and it is also hoped that the realization of positive activities towards education will be even better. Education contributing to the success of development in the agricultural sector is not solely determined by development in the technology sector but is determined by the development of the quality of human resources, aspects of human personality, which include knowledge, values, attitudes and skills. The influence of globalization encourages education in the agricultural sector to be increasingly encouraged by stakeholders to always be improved so that the agricultural sector becomes more productive.
\end{abstract}

Keywords: Education, Globalization, Philosophy, Agriculture

\section{Introduction}

Globalization is a global process of community order and knows no boundaries. Globalization is essentially a process from which ideas are raised, then offered to be followed by other nations which eventually arrive at a point of mutual agreement and become a common guide for nations around the world. The process of globalization takes place in two dimensions, namely the dimensions of space and time. Globalization takes place in all fields of life such as ideology, politics, economics, and especially in the field of education. Information and communication technology is a major supporting factor in globalization (Torres, 2002). Nowadays, information and communication technology is developing rapidly with various forms and interests can be spread throughout the world. Therefore, globalization cannot be avoided, especially in the field of education (Çelik \& Gömleksiz, 2000).

The advancement of science and technology accompanied by the increasingly fast current of globalization has had its own impact on the world of education. Many schools in Algeria have in recent years started to globalize the internal school education system. This can be seen in schools known as billingual schools, with the application of foreign languages such as English and Mandarin as compulsory school subjects. In addition, various levels of education ranging from high school to higher education, both public and private, have opened international class programs. The globalization of education is carried out to answer the increasingly stringent market needs for quality labor. With the globalization of education, it is hoped that the Algerian workforce can compete in the world market. Moreover, with the 
implementation of free trade, for example within the scope of African countries, inevitably the world of education in Algeria must produce graduates who are ready to work.

Competition to create a country that is strong, especially in the economic field, so that it can be included in the ranks of the world's economic giants, of course, really requires a combination of capable brain skills accompanied by high creative skills (Florida, 2010). One of the keys is the globalization of education combined with the rich culture of the Algerian people. In addition, improving the quality of education should be in line with the current conditions of the Algerian community. We cannot deny that there are still many Algerians who are below the poverty line. In this case, to be able to enjoy good quality education, of course, requires a large amount of money. Of course this is one of the causes of the globalization of education that has not been felt by all circles of society. For example, to be able to enjoy international class programs at leading universities. As a result, this can only be enjoyed by the established upper class. In other words, progress is more advanced, and marginalized groups will be increasingly marginalized and drowned in the increasingly tense current of globalization that can drag them into the abyss of poverty. The upper class people send their children to luxury schools at a time when the economically weak people have to bother even to just send their children to ordinary schools.

\section{The Relationship between Philosophy and the World of Education}

Efforts to develop the human potentials of students, both physical potential, creative potential, taste, and character, so that this potential becomes real and can function in the course of their life. The basis of education is the ideal of universal humanity. Education aims to prepare a personal balance, unity. organic, harmonious, dynamic. in order to achieve the goals of human life (Renzulli, 2012). Educational philosophy is a philosophy used in the study of educational problems. The purpose of educational philosophy provides inspiration on how to organize an ideal learning process. Educational theory aims to produce thoughts about educational policies and principles based on educational philosophy. Educational practice or the educational process implements a series of activities in the form of curriculum implementation and interaction between teachers and students in order to achieve educational goals by using signs from educational theories.

In various fields of science we often hear the terms vertical and horizontal. This term will also be heard in the branch of philosophy and even educational philosophy. Between philosophy and education there is a horizontal relationship, extending sideways, namely the relationship between different branches of scientific disciplines, so that it is a synthesis which is the application of science in the field of life, namely philosophy in the adjustment of educational and teaching problems. Educational philosophy is thus a pattern of thought or a philosophical approach to problems in the field of education and teaching. The philosophy of education shows a vertical relationship, rising up or down with other branches of education, such as the introduction of education, history of education, educational theory, comparative education and the peak of educational philosophy.

philosophy as a way to organize, and harmonize the educational process. This means that the philosophy of education can explain the values and edicts that are sought to achieve them, then the philosophy of education and human experience are integral factors or a unity. Meanwhile, philosophy is also defined as implementing the philosophical views and principles of philosophy in the field of education, this philosophy describes one aspect of implementing general philosophy and focuses on the implementation of the principles and beliefs that are 
the basis of general philosophy in an effort to solve problems. practical education issues (Hirst, 2010; O'Connor, 2016).

Philosophy of education is a formation of fundamental basic abilities, both concerning the power of thought (intellect) and power of feeling (emotional), towards human nature, then philosophy can also be interpreted as a general theory of education. The functional relationship between philosophy and educational theory is as follows: (1) Philosophy, in a philosophical sense, is an approach used in solving educational programs and compiling educational theories by experts. (2) Philosophy, serves to provide direction for existing educational theories according to certain philosophical schools that have relevance to real life. (3) Philosophy, in this case the philosophy of education, has a function to provide guidance and direction in the development of educational theories into educational science (pedagogy).

\section{Vertical Relationship between educational philosophy and certain disciplines}

The relationship between the level of mastery or expertise and the deepening of similar knowledge clumps. Therefore, the philosophy of education as one not the only applied science is a branch of science that focuses its attention on the application of a philosophical approach to the field of education in order to improve the welfare of life and livelihoods of humans in general and humans who are predicated as educators or teachers in particular (Calvo \& Peters, 2014). The relationship between philosophy and education is very close to one another. The strength of this relationship is due to the fact that the two disciplines face the problems of philosophy together.

\section{The influence of globalization on the world of education}

The development of education in Algeria cannot be separated from the influence of the development of globalization, where science and technology are developing rapidly. The era of free markets is also a challenge for the education world in Algeria, because there are opportunities for educational institutions and educators from abroad to enter Algeria. To face the global market, national education policies must be able to improve the quality of education, both academic and non-academic, and improve education management to be more productive and efficient and provide the widest possible access for people to get education (Murphy et al., 2001; Ouane \& Glanz, 2010). The nation's unpreparedness in producing quality and moral human resources who are prepared to be involved and take part in the globalization arena, has resulted in positive and negative impacts from the effects of globalization in education.

\section{Positive Impact of Globalization on the World of Education}

Technological advances due to the rapid flow of globalization, change the pattern of teaching in the world of education. Classical teaching has turned into teaching based on new technologies such as the internet and computers. In the past, teachers wrote with a stick of chalk, occasionally drawing simple pictures or using sounds and other simple means to communicate knowledge and information. Now there is a computer. So that writing, film, sound, music, live pictures, can be combined into a communication process.

\section{The Influence of Globalization and Education on Agriculture}

Education contributing to the success of development in the agricultural sector is not solely determined by development in the technology sector but is determined by the development 
of the quality of human resources, aspects of human personality, which include knowledge, values, attitudes and skills. Ideas and thoughts related to the dynamics of global development entering the industrial revolution volume 4.0, where information technology has far advanced in influencing human existence. Efficiency and productivity alone are not sufficient to become a global agricultural actor. It needs innovation, creativity and spirit of intrepeneurship through strengthening integrated agricultural solidity which is very relevant in global agricultural competition.

\section{Conclusion}

Philosophy of education as one of not the only applied sciences is a branch of science that focuses its attention on the application of a philosophical approach to the field of education in order to improve the welfare of life and livelihoods of humans in general and humans with predicate as educators or teachers in particular. It is hoped that the public can better understand the importance of globalization so that the negative impacts that have an impact can be minimized and it is also hoped that the realization of positive activities towards education will be even better. To face the global market, national education policies must be able to improve the quality of education, both academic and non-academic, and improve education management to make it more productive and efficient and provide the widest possible access for people to get education. Efficiency and productivity alone are not sufficient to become a global agricultural actor. It needs innovation, creativity and the spirit of intrepeneurship through strengthening agricultural solidity which is supported by education about agriculture.

\section{References}

Calvo, R. A., \& Peters, D. (2014). Positive computing: technology for wellbeing and human potential. MIT Press.

Çelik, V., \& Gömleksiz, M. N. (2000). A critical examination of globalization and its effects on education. Fırat Üniversitesi Sosyal Bilimler Dergisi, 10(2), 133-144.

Florida, R. (2010). Who's your city?: How the creative economy is making where to live the most important decision of your life. Vintage Canada.

Hirst, P. H. (2010). Knowledge and the curriculum (International Library of the Philosophy of Education Volume 12): A collection of philosophical papers. Routledge.

Murphy, J., Beck, L. G., Crawford, M., Hodges, A., McGaughy, C., \& Slamp, A. (2001). The productive high school: Creating personalized academic communities. Corwin Press.

O'Connor, D. J. (2016). An introduction to the philosophy of education. Routledge.

Ouane, A., \& Glanz, C. (2010). How and why Africa should invest in African languages and multilingual education. UNESCO Institute for Lifelong Learning.

Renzulli, J. S. (2012). Reexamining the role of gifted education and talent development for the 21st century: A four-part theoretical approach. Gifted Child Quarterly, 56(3), 150-159.

Torres, C. A. (2002). Globalization, education, and citizenship: Solidarity versus markets?. American educational research journal, 39(2), 363-378. 